\title{
Changes in U.S. and Canadian Wage Dynamics in the 1990s: How Unique Are Favorable U.S. Labor Market Developments?
}

\author{
Mark D. Partridge*
}

\begin{abstract}
One of the most notable recent U.S. economic developments is the sharp decline in the unemployment rate without a corresponding increase in inflation. This favorable change suggests that the labor market has undergone some important structural shifts. This study uses U.S. state-level data to evaluate this possibility. Canadian provincial-level models are also estimated for comparison. The results indicate that U.S. and Canadian regional wage dynamics were different in the 1990s than the 1980s. The U.S. findings are consistent with "new economy" interpretations and the results suggest that standard Phillips curve models may be unsuitable for both nations
\end{abstract}

\section{INTRODUCTION}

One of the most notable U.S. economic developments of the 1990s is the sharp decline in the unemployment rate (to about 4 percent) without an accompanying increase in wage and price inflation. With a few exceptions (e.g., U.K.), the U.S. experience has been rather atypical among advanced economies (Katz and Krueger 1999). Before the latter 1990s, most economists would have thought that such favorable developments would be unlikely. For example, Gordon (1997, 1998) notes that the upturn in wage and price inflation in the latter 1980 s occurred as the U.S. unemployment rate fell below 6 percent, which was the prevailing estimate of the NAIRU.

The robust experience of the U.S. economy has set off a wave of studies trying to explain these events. Gordon (1998) argues that much of the pleasant inflation-unemployment rate story of the latter $1990 \mathrm{~s}$ is due to measurement changes in price indices; favorable supply shocks to food, energy, computers, and health care; and rapid appreciation of the dollar. He contends that most of these shifts are transitory, and that historical patterns will reemerge. Others maintain that new information technologies (IT) have permanently boosted productivity growth (e.g., see Jorgenson and Stiroh 2000). These "new economy" advocates argue that the unemployment-inflation rate trade-off is irrelevant or of diminished importance (Mandel 1999).

Others contend that fundamental changes in the labor market are primarily behind recent developments (e.g., Stock 1998; Katz and Krueger 1999). Foremost, there is a consensus (at least among those who believe in its existence) that the NAIRU declined in the 1990s (Stiglitz 1997; Gordon 1997, 1998; Freeman and

*Department of Economics, St. Cloud State University, St. Cloud, MN. 
Rodgers 1999; Katz and Krueger 1999; Phelps 2000). However, there is less agreement regarding why the NAIRU declined, although explanations include demographic trends, worker anxieties, greater use of temporary workers, welfare reform, and a larger prison population.

Besides changes in the NAIRU, Stock (1998) suggests even more fundamental changes. For instance, unlike the apparent shift in the inflation-unemployment rate association, the relationships between inflation and capacity utilization and other economic measures have been stable in the 1990s (Stock 1998; Brayton, Roberts, and Williams 1999). This suggests that in answering why wage inflation remains low in the face of very low unemployment rates, recent labor market developments need to be explored. In this manner, this paper will investigate regional labor market changes during the 1990s by combining the methodologies used in Phillips curve analysis with the wage curve (Blanchflower and Oswald 1994). Yet, this paper will not be another study that estimates a specific NAIRU. Instead, the emphasis will be on changes in the underlying regional labor market dynamics as well as an examination of how the wage inflation-unemployment rate trade-off has adjusted. Both factors are crucial in judging labor market shifts.

A major drawback of examining the U.S. in isolation is that similar changes may have occurred elsewhere because all advanced economies have been exposed to similar technological and global forces. That is, suppose that there were similar changes in the wage dynamics of Europe, with its high unemployment-low inflation environment. Then these changes are less likely to have produced the favorable U.S. outcome. Yet, it is difficult to model empirically the U.S. and European labor markets in the same framework due to vastly different institutional and economic arrangements.

Modeling the U.S. and Canadian labor markets, by contrast, provides a more reliable natural experiment (e.g., Card and Riddell 1993; Freeman 1998). The two nations possess considerable social and economic similarities. Both have been exposed to the same technological and globalization trends and they are closely linked by being the world's largest trading partners. Moreover, they both had similar inflation rates over the last thirty years, which suggests comparable monetary policies and inflationary expectations over the period. Indeed, until the early 1980s, both labor markets had similar unemployment rates. Given their likeness, it is reasonable to assume that the Canadian and U.S. labor markets can be modeled in an analogous fashion. Yet, despite their similarities, Canada and the U.S. do differ in terms of labor market flexibility. Canada is viewed as somewhere between the flexible "American" model and the sclerotic European model (Card, Kramarz, and Lemieux 1996). Like Europe, Canada has stronger unions, generous welfare programs (notably, unemployment insurance (UI)), and more stringent government regulations. Also, like Europe, Canada's unemployment rate has been 2 to 5 percentage points above the U.S. level since the mid-1980s. Finally, during the 1990s, the U.S. experienced both rising employment/population and 
labor force participation rates, while Canada, again like Europe, experienced the opposite until the very end of the 1990s (U.S. Department of Labor 1999).

Thus, comparing the U.S. to Canada provides a better natural experiment. We can be more confident that differences in wage dynamics between the two reflect factors that underlie the favorable U.S. performance. In this manner, this study uses 1983-1997 state- and provincial-level data to examine wage dynamics and to assess whether these dynamics shifted in the 1990s. The use of subnational data greatly increases the cross-sectional variation, making it easier to identify labor market shifts.

Section 2 first reviews some typical theoretical labor market models. Then, following Blanchard and Katz (hereafter BK) $(1997,1999)$, these models will be reconciled with Phillips curve models. Section 3 describes the empirical implementation and data. Section 4 first describes the U.S. empirical results then presents a comparison with the Canadian results. This analysis detects key shifts in U.S. and Canadian wage dynamics in the 1990s. Final thoughts are presented in the concluding section.

\section{MODEL}

Theoretical bargaining and efficiency wage models often incorporate a "wage curve" or a "supply-wage relationship" that suggests a positive association between the wage level and labor market tightness, given the reservation wage and the productivity level. The reservation wage is influenced by factors such as UI, wage aspirations, household production, and nonlabor income, all of which are likely related to productivity and real wages. Thus, it has been suggested that lagging wage aspirations can help explain rising unemployment after the energy and productivity shocks of the 1970 s as well as declining unemployment coinciding with the 1990s productivity rebound (Stiglitz 1997). Also, because unemployment rates have been approximately stationary over time, the reservation wage must rise with (trend) productivity and the real wage (BK 1997; Katz and Krueger 1999).

Given these conditions, BK (1999) show that under reasonable assumptions, the log of the expected real wage level can be depicted by:

$$
\left(w_{t}-p_{t}^{e}\right)=\alpha+\tau\left(w_{t-1}-p_{t-1}\right)+(1-\tau) x_{t}+\beta \operatorname{CYCLICAL~}_{t}+e_{t}, 0 \leq \tau \leq 1,
$$

where $\mathrm{w}$ is the log wage, $\mathrm{p}$ is the log price level, and $\mathrm{x}$ is the labor productivity level. CYCLICAL is a labor market tightness measure that may include lag terms, $\mathrm{e}$ is a residual, and $\alpha$ and $\beta$ are parameters. CYCLICAL is often assumed to be the unemployment rate or the capacity utilization rate, in which cases $\beta$ is negative and positive. Equation 1 implies that expected real wages are positively related to labor market tightness and a weighted average of the lagged real wage and the current productivity level. 
Substituting the current price level for the expected price level (assuming rational expectations), Equation 1 can be rewritten as:

$$
\Delta \mathrm{rw}_{\mathrm{t}}=\alpha-(1-\tau)\left(\mathrm{w}_{\mathrm{t}-1}-\mathrm{p}_{\mathrm{t}-1}-\mathrm{x}_{\mathrm{t}-1}\right)+\beta \mathrm{CYCLICAL}_{\mathrm{t}}+(1-\tau) \mathrm{g}_{\mathrm{t}}+\mathrm{e}_{\mathrm{t}},
$$

where rw is the real wage and $g$ is the productivity growth rate. Among other things, Equation 2 suggests that growth in real wages is a function of the difference of the lagged real wage level and the level of productivity, which reflects an "error-correction" term. The error-correction term implies that if real wage levels significantly rise above levels justified by productivity, real wage growth will decline.

Alternatively, the Phillips curve denotes the relationship between a change in a price or wage level and an indicator of the intensity of demand in the economy. Phillips curve models generally rely on some variant of the "triangle" model (Gordon 1997), with inflation being determined by supply and demand factors as well as inertia. The Phillips curve for wage inflation can be represented as: ${ }^{1}$

$$
\left(w_{t}-w_{t-1}\right)=\alpha_{w}+\left(p_{t}^{e}-p_{t-1}\right)+\beta \operatorname{CYCLICAL}_{t}+e_{t},
$$

or nominal wage growth equals $\alpha_{w}$ plus expected inflation adjusted for labor market tightness. By substituting the actual price level for the expected price level, Equation 2 can be rearranged to obtain Equation 3 by moving current and lagged inflation to the right-hand side and assuming $\tau$ equals one-or that there is no error correction in wage dynamics.

The absence of an error-correction term in Phillips curve models as opposed to the more theoretically grounded wage curve in Equation 1 has set off a debate. Blanchflower and Oswald (1994) argue that there is little or no autoregressive component in wage levels, meaning that the Phillips curve is really a misspecified wage curve. Yet, BK (1999) show that if simultaneously there is (1) no direct effect of productivity on wages (given the reservation wage) and (2) no direct effect of productivity on the reservation wage, then the error-correction term drops out of the wage curve model, making it consistent with the Phillips curve. ${ }^{2}$ Moreover, BK $(1997,1999)$ argue that the empirical evidence is more consistent with there being no error-correction term for the U.S. $(1-t \approx 0)$, but an errorcorrection effect for Europe $(1-t \approx .25)$ (also Brayton, Roberts, and Williams 1999; Dalenberg and Partridge 2000). That is, the Phillips curve is a good representation for the U.S., but not Europe. They suggest that this important disparity implies dramatically different wage dynamics, including a stronger link between supply shocks (e.g., oil shocks) and the European NAIRU (compared to the U.S.).

BK (1999) propose some reasons for different U.S. and European wage behavior, including greater importance of unionization and the underground

${ }^{1}$ In Equation 3, $\alpha_{w}$ may be viewed as factors that increase wages over time, such as trend productivity growth. Franz and Gordon (1993) formally present more complex Phillips curve derivations.

${ }^{2}$ For other reasons, Whelan $(1997,1999)$ contends that the wage curve and Phillips curve can coexist 
economy in Europe. Likewise, they contend that European wages may be more linked to firm productivity. Yet, the link between institutions and economic outcomes can change (Freeman 1998; Nickell 1998). For example, the large changes in U.S. labor markets during the 1990s suggest that the error-correction term may be more important in wage determination. Freeman $(1998,2000)$ and Schlesinger (1999) argue that in recent years an "American" model of greater employee participation and a closer linkage of compensation and firm (and worker) performance has developed (e.g., stock options and performance-related bonuses). Greater use of temporary workers in the 1990s may also affect Phillips Curve relationships (Katz and Krueger 1999; Nordhaus 1999). Finally, new IT may improve the job search process (Stock 1998). These trends imply that the error-correction term in U.S. wage dynamics may have changed (as well as $\beta$ ).

Changes in the sensitivity of wages to cyclical conditions $(\beta)$ are also important. Greater wage flexibility in response to labor market tightness smoothes cyclical effects. In a Phillips curve model with unemployment rates, the NAIRU is inversely related to the absolute value of the sum of the unemployment rate coefficients, ceteris paribus (see Footnote 9). Riddell and Sharpe (1998) suggest that strong Canadian wage rigidity may explain some of the U.S.-Canadian unemployment gap. Reasons for a smaller Canadian wage responsiveness to cyclical conditions include greater unionization, higher payroll taxes, and a more binding minimum wage. ${ }^{3}$ Moreover, at the subnational level, relative wage changes can induce cross-regional migration from high unemployment areas to labor-short areas.

Unlike NAIRU models of unemployment, strong hysteresis, or sluggishness, suggests that wage inflation is only related to changes in the unemployment rate, not to the level of the unemployment rate. Regarding wage determination, strong hysteresis implies that the sum of the coefficients on the CYCLICAL term is zero, which means that there is no NAIRU (when using the unemployment rate). Blanchard and Summers (1986) contend that hysteresis is a key reason for persistently high European unemployment rates. Yet, the relative importance of hysteresis is controversial. Jaeger and Parkinson (1994) find strong hysteresis effects for Canada, Germany, and the U.K., but not for the U.S., while Fortin (1996) finds strong hysteresis for Canada. ${ }^{4}$ Conversely, Song and Wu (1998) find evidence inconsistent with hysteresis for 15 OECD countries. Whether hysteresis describes labor market dynamics is consequential because it suggests that labor markets are inflexible and that government demand policies can permanently alter unemployment rates.

The "Goldilocks" economy of falling U.S. inflation rates along with declining unemployment rates has prompted some enthusiastic observers to proclaim a "new economy." New Economy advocates contend that recent adoptions of IT

${ }^{3}$ Kuhn and Robb (1998) find supporting evidence that greater Canadian wage inflexibility produced higher unemployment in the 1980s and 1990s, especially for lower-skilled workers.

${ }_{4}^{4}$ There are several potential reasons for hysteresis. For example, skills of the long-term unemployed erode or long-term unemployment is a negative signal to employers. Insider-outsider models also suggest that the longterm unemployed are the ultimate outsiders (Lindbeck and Snower 1988). 
have rendered labor constraints mostly irrelevant (Mandel 1999; McTeer 1999). Proponents contend that foreign sources can alleviate domestic production bottlenecks, further tempering supply and demand constraints. In its strongest form, the new economy view suggests that there is no longer a NAIRU anchor that limits economic growth or that labor market tightness has no medium-run influence on wage or consumer inflation. Indeed, Stock (1998) found some evidence that labor market tightness had no influence on inflation after 1993, while Katz and Krueger (1999) found weak evidence that the Phillips curve was flatter in the 1990 s. $^{5}$ Ironically, even as the origins of hysteresis models (high European unemployment) differ from the origins of the new economy view (strong U.S. growth without inflation), they have similar empirical implications for $\beta$.

The answer to whether $\beta$ has changed not only has implications for understanding regional labor market dynamics, but also for the conduct of monetary policy. For example, an assumption of the dynamic time inconsistency theory of monetary policy is that the central bank cannot credibly commit to the optimal long-term policy of low inflation at the NAIRU. Hence, it will try to exploit shortrun gains in lower unemployment rates, but this comes at the cost of accelerating inflation rates as inflationary expectations begin to incorporate this behavior (Kydland and Prescott 1977). Parkin (1993), Ireland (1999), and Sargent (1999) contend that the time inconsistency argument can explain the subsequent rise in Canadian and U.S. inflation in the 1970s followed by falling inflation in the 1980s, although De Long (1997), Taylor (1997), and Mayer (1999) disagree. Regardless of whether the time inconsistency hypothesis can explain past behavior, a flatter Phillips curve does imply that there is a more favorable short-term trade-off between inflation and unemployment (or job growth). Hence, a shortsighted central bank may be more likely to take advantage of short-term reductions (increases) in unemployment (job growth) because the cost is only a modest increase in inflation, which would eventually produce much higher inflation.

Using aggregate national data in estimating Equations 1-3 is problematic. Concerns include limited sample size, questions as to the factors to include in the model, appropriate productivity measures, and even spurious trends. Yet, most of these problems can be overcome by using pooled cross-sectional regional data (BK 1992, 1997; Blanchflower and Oswald 1994; Dalenberg and Partridge 2000). Modeling regional wage inflation is quite similar to the aggregate case. Yet, a key simplifying assumption is that inflation rates, exchange rate shocks, monetary regime, and productivity growth effects that are common across regions within the nation can be captured by the time fixed effects. ${ }^{6}$ In a regional model, expected real wage growth in region $\mathrm{s}$ in period $\mathrm{t}$ can be written as:

$$
\Delta \mathrm{rw}_{\mathrm{st}}=\mathrm{a}_{\mathrm{ws}}-(1-\tau)\left(\mathrm{w}_{\mathrm{st}-1}-\mathrm{p}_{\mathrm{t}-1}-\mathrm{x}_{\mathrm{st}-1}\right)+\beta C Y C L I C A L_{\mathrm{st}}+\sigma_{\mathrm{t}}+\mathrm{e}_{\mathrm{st}},
$$

${ }^{5}$ Gordon (1998) provides a strong dissenting view of the new economy hypothesis.

${ }^{6}$ The time fixed effects capture all common effects across regions. For example, some observers have attributed sluggish wage growth to a general anxiety among workers (Greenspan 1997). If there were a common anxiety in the nation that has reduced wage growth, it would be reflected empirically in the year fixed effects. Similar effects apply for national new economy factors. 
where $a_{w s}$ represents the regional (state or provincial) fixed effect, $\sigma_{t}$ is a year fixed effect, and e is an error term. A standard Phillips curve can be derived from Equation 4 by assuming that $\tau$ equals one and that inflation is common across all regions (this simply subsumes inflation into the time fixed effect). A common inflation rate appears to be a reasonable assumption, where national monetary policy should almost entirely equilibrate long-run inflation across the nation. ${ }^{7}$

\section{EMPIRICAL IMPLEMENTATION}

\section{Empirical Equation}

The empirical model will be separately estimated for each country. To show the empirical implementation for each nation, Equation 4 is re-expressed:

$$
\Delta \mathrm{rw}_{\mathrm{st}}=\mathrm{a}_{\mathrm{ws}}+\beta C Y C L I C A L_{\mathrm{st}}-\pi \mathrm{rw}_{\mathrm{st}-1}+\Theta \mathrm{X}_{\mathrm{st}-1}+\sigma_{\mathrm{t}}+\mathrm{e}_{\mathrm{st}}
$$

where the error-correction term has been decomposed into a lagged real wage term and the vector $\mathrm{X} .{ }^{8} \mathrm{X}$ contains variables related to the lagged productivity level as well as other factors, including wage aspirations and the reservation wage. The coefficient $\pi$ equals $1-\tau$, while $\Theta$ is a coefficient vector that reflects a combination of $1-\tau$ and the productivity effects for the elements in X. A regionallevel Phillips curve is a special case of the regional wage curve in Equation 5, with the restriction that $\pi=0.9^{9}$ Thus, the Phillips curve model would be supported if $\pi$ is empirically insignificant.

The state or provincial fixed effect $a_{w s}$ accounts for possible persistent differences in regional real wage growth. Some possible reasons include migration (perhaps due to amenities), differences in labor market institutions and structure, productivity differences, unmeasured demographic effects, or state/province business climate. If the independent variables are correlated with the unmeasured factors that compose these fixed effects, not including regional fixed effects biases the other variable coefficients.

Despite their similarities, there are some differences between regionallevel and national-level wage dynamics. In particular, migration of labor and capital suggests that a regional labor market can adjust faster to shocks than the aggregate labor market. Greater labor force migration in the U.S. suggests that U.S. labor markets are relatively flexible (BK 1992; Decressin and Fatás 1995; Partridge and Rickman 1995, 1999). Compared to aggregate national models, migration can affect the estimated regional-level coefficients in Equation 5. For example, a major

\footnotetext{
7For an example of an earlier U.S. regional labor market study, see Hyclak and Johnes (1992). Likewise, see Johnson and Kneebone (1993) for an earlier provincial wage study.

${ }^{8}$ Pooling can lead to problems when there are different regional responses. Yet, by utilizing the greater sample size and controlling for a large number of factors that vary across regions (including time and region fixed effects), the problems of differential regional responses are greatly mitigated. The pooled findings generally reflect an average response for the nation, which is the goal of this study.

In the standard Phillips curve model of wage changes (i.e., $\Theta=0$ ) with only unemployment rates in the CYCLICAL term, the regional NAIRU is simply $-a_{w s} / \Sigma(\beta)$ (ignoring $\sigma_{t}$ ). Ceteris paribus, the more flexible wages are to cyclical conditions (a larger absolute value of the sum of the $\beta$ 's), the lower is the NAIRU. However, the augmented model in Equation 5 is not well suited to estimate a specific national NAIRU.
} 
determinant of migration is relative wages across regions, or regional wages relative to the national average. Empirically, some of this aggregate wage effect could be captured by the state and time dummies, biasing $\pi$ to zero (BK 1999). Likewise, some cyclical effects that are common across regions may also be captured in the time fixed effects (e.g., during a recession), which can bias $\beta$ to zero. Yet, BK (1999) note that Equation 5 should still accurately reflect the effects of regional economic shifts. Therefore, examining wage dynamics at the regional level yields some major empirical advantages, but there are some differences in interpretation.

\section{Data}

The two separate data sets correspond to the 10 Canadian provinces and the lower 48 U.S. states, both from 1984-1997. This period was chosen primarily to ensure coverage during the 1980 s and 1990s economic expansions. Moreover, by beginning the sample in 1984, I avoid modeling problems that arise from the structural changes that occurred as the inflation rate sharply declined after 1980, when monetary policy shifted from being expansionary to contractionary (Mayer 1999; Sims 1999). The dependent variable is the change in the log real average weekly wage. For the U.S., the weekly wage is for private sector workers covered by UI deflated by the consumer price index $(1982-84=100) \cdot{ }^{10}$ The Canadian weekly wage is for all civilian workers deflated by the provincial CPI $(1992=100) .{ }^{11}$ Using weekly earnings accounts for changes in the hourly wage and changes in average hours. This measure answers how cyclical movements influence total labor earnings, including changes due to labor utilization. BK's (1997) results were virtually unaffected by using hourly wages or UI weekly earnings, although sensitivity analysis will be conducted using hourly wages. ${ }^{12}$

The most commonly used measure of conditions in the CYCLICAL vector is the unemployment rate. Most studies use the contemporaneous unemployment rate even though it may be endogenously related to current wages (e.g., Staiger, Stock, and Watson 1997). Gordon (1998, p. 303) argues that this is a minor concern because "unemployment causes inflation in a Granger causation sense." The current study follows that tradition, but the possible endogeneity of the contemporaneous labor market measure is closely examined. Hysteresis, or sluggish wage adjustment, suggests that wages do not just respond to the unemployment rate,

10The source for state weekly wages is the ET Handbook No. 394 at <www.itsc.state.md.us>.

11 Unlike the U.S., Canada produces an inflation price index by province (the U.S. average is used for states). However, the provincial index only reflects changes in the provincial price level relative to 1992 (where provincial inflation rates are very highly correlated), and does not reflect differences in provincial price levels. Like the U.S., persistent differences in provincial price levels (New Brunswick versus British Columbia or South Dakota versus California) are reflected in the provincial (or state) fixed effects. Unless otherwise indicated, all Canadian data are from Statistics Canada (1998).

12BK (1997) present a variety of specifications using U.S. state data from 1980-1991 (average weekly earnings for workers covered by UI, average hourly manufacturing wages, and hourly wages from the outgoing sample of the CPS). These results are essentially the same, with 1-t ranging from 0.03 to 0.09 . Alternatively, they can essentially replicate Blanchflower and Oswald's (1994) wage curve results of 1- $\tau$ being close to 1 when they use annual earnings from the CPS. BK (1997) attribute this finding to confounding weeks worked with average wages and to measurement error from small-state sample sizes in the CPS. However, Dalenberg and Partridge (2000) find that UI weekly wages and average annual wages from the Bureau of Economic Analysis (not as prone to smallstate measurement error) yield very similar results (suggesting that CPS measurement error is the primary cause). 
but also to changes in the unemployment rate (Franz and Gordon 1993; Gordon 1997). Thus, two unemployment rate lags are included to capture both change and level effects. ${ }^{13}$ Including two lags has the advantage of allowing a flexible lag structure for both nations to improve the comparability of the results. Yet, including all three unemployment rates comes at the expense of introducing three highly correlated variables, which may reduce their statistical significance.

In national Phillips curve specifications, the unemployment rate worked well as a measure of cyclical demand until the 1990s. However, Staiger, Stock, and Watson (1997) and Stock (1998) note that other indicators, such as capacity utilization and employment growth, have been better predictors of inflation in the 1990s.

At the state and provincial level, using the unemployment rate as a measure of labor market tightness is confounded further. Regional migration and persistent differences in mean regional unemployment rates complicate assessing aggregate demand with just unemployment rates (BK 1992; Partridge and Rickman 1995, 1997b). That is, equilibrium unemployment rate differences across regions may reflect compensating differentials for amenities. Similarly, the Harris-Todaro model suggests a positive hedonic trade-off between wages and unemployment rates (Harris and Todaro 1970; Partridge and Rickman 1997a). For example, many southern states traditionally have unemployment rates that approximately equal the national average, even as in-migration has resulted in large employment growth rates. Conversely, most Plains states (and Prairie provinces) have low unemployment rates, but negative net migration rates have produced relatively low employment growth rates. One implication is that regional unemployment rates may not adequately reflect cyclical activity. Thus, contemporaneous nonfarm employment growth and its two lags are also used as cyclical indicators, which allows an assessment of which labor market measure is superior. ${ }^{14}$

The lagged productivity level in the state $\left(X_{s t-1}\right)$ will be controlled for by using lagged measures of human capital, institutional effects, labor force attachment, and labor quality - or factors generally accepted as being correlated with productivity and wages in micro wage specifications (and some are likely related to the reservation wage). Their inclusion reflects a difference from standard Phillips curves, but inadequately controlling for labor force heterogeneity is believed to bias the responsiveness of wages to cyclical conditions countercyclically (Solon, Barsky, and Parker 1994).

Katz and Krueger (1999) contend that an important factor for the apparent decline in the U.S. NAIRU in the 1990s is age distribution changes that affect labor force attachment and potential labor supply. Parkin (1993) argues that a similar pattern exists for Canada, although for different reasons. Thus, the population shares between 15 and 19 years old, 20 and 24 years old, 55 and 64 years old, and

\footnotetext{
${ }^{13}$ As Gordon (1998) points out, the significance of the sum of the unemployment rate coefficients is the level effect, while movements in the unemployment rate coefficients are the change effect.

${ }_{14}$ Unemployment rate data are from the U.S. Department of Labor's Geographic Profile of Employment and Unemployment. Employment data are from the Bureau of Labor Statistics, available at:

<http://stats.bls.gov:80:datahome.htm>.
} 
65 years and older are added to the model. ${ }^{15}$ The percent unionized is included to account for differences in productivity and worker bargaining power. Some analysts have suggested that sluggish U.S. wage growth is related to the decline of unions (Gordon 1998). U.S. unionization is measured as the percent of state nonfarm employment who are union members while provincial unionization is measured as the percent of the civilian labor force who are union members. ${ }^{16}$ Educational attainment is included to control for human capital effects. Two U.S. attainment variables are included: (1) the share of the population (25 years old or older) with a high school degree, but not a four-year college degree; and (2) the population share with a four-year college degree. The Canadian model includes (1) the percent of the population 25 and over with 9 to 13 years of schooling; (2) the percent with some college but not a university degree; and (3) the percent with a (four-year) university degree. ${ }^{17}$ Canadian educational attainment is measured differently primarily because high school graduates can have between 11 and 13 years of schooling depending on province. To account for labor supply and reservation wage effects, the second lag value of the log of real average weekly UI benefits is included in the model (renamed employment insurance in Canada). Using the lag value mitigates the potential endogeneity that arises when average benefits increase in a recession due to a composition effect, while still accounting for persistent differences in UI generosity across states/provinces.

To account for structural and productivity differences by sector, the U.S. model includes lagged nonfarm employment shares for manufacturing and mining and the lag civilian employment share in farm occupations. ${ }^{18}$ The Canadian model includes the lag civilian farm employment share and the lag nonfarm employment shares for manufacturing and other-primary (mostly mining and logging).

\section{EMPIRICAL RESULTS}

Table 1 presents the unweighted descriptive statistics. For example, the change in the Canadian log real weekly wage suggests an annual decline of about 0.2 percent over the 1984-1997 period versus an average increase of 0.25 percent in the U.S. The descriptive statistics also illustrate the stronger U.S. labor market. State nonfarm employment growth averaged 0.9 percentage point more than the corresponding provincial employment growth rate, while provincial unemployment rates averaged over 5 percentage points higher.

\footnotetext{
15U.S. age shares are from the Bureau of the Census, available at:

<http://www.census.gov/population/www/estimates/statepop.html>.

16U.S. union densities are from the U.S. Department of Commerce's Statistical Abstract of the United States and Hirsch and Macpherson (1993). Provincial union densities were directly provided by Statistics Canada and were drawn from the CALURA firm survey and the Labor Force Survey.

17U.S. education data for 1980 and 1990 are from the U.S. Census of Population and from the Bureau of Census publication Educational Attainment in the United States for 1993, 1995, 1996, and 1997. Education for intervening years was interpolated. Educational attainment for Canada is from the 1981, 1986, 1991, and 1996 Census of Population, where the data was interpolated for intervening years.

18U.S. manufacturing and mining share data are from the Bureau of Labor Statistics web site and the farm occupation share is from the U.S. Department of Labor's Geographical Profile of Employment and Unemployment.
} 
TABLE 1

Canadian and U.S. Means (std dev)

\begin{tabular}{|c|c|c|}
\hline & Canada & U.S. \\
\hline$\Delta \operatorname{Ln}(\text { Real Weekly Wage })_{t}$ & $\begin{array}{l}-0.002 \\
(0.015)\end{array}$ & $\begin{array}{r}0.0025 \\
(0.017)\end{array}$ \\
\hline $\operatorname{Ln}(\text { Real Weekly Wage })_{t-1}$ & $\begin{array}{l}6.24 \\
(0.076)\end{array}$ & $\begin{array}{l}5.76 \\
(0.13)\end{array}$ \\
\hline Annual Nonfarm Employment Growth ${ }_{t}$ & $\begin{array}{l}0.015 \\
(0.0197)\end{array}$ & $\begin{array}{c}0.024 \\
(0.021)\end{array}$ \\
\hline Unemployment Rate $_{\mathrm{t}}$ & $\begin{array}{l}11.3 \\
(3.72)\end{array}$ & $\begin{array}{l}6.0 \\
(1.80)\end{array}$ \\
\hline$\%$ Union $_{t-1}$ & $\begin{array}{l}34.67 \\
(7.04)\end{array}$ & $\begin{array}{l}14.8 \\
(6.1)\end{array}$ \\
\hline Ln(Real Avg. Weekly UI) $)_{t-2}$ & $\begin{array}{l}5.43 \\
(0.076)\end{array}$ & $\begin{array}{r}4.76 \\
(0.17)\end{array}$ \\
\hline$\% 9 \leq$ Years Educ $\mathrm{c}_{\mathrm{t}-1} \leq 13$ & $\begin{array}{l}37.87 \\
(1.43)\end{array}$ & \\
\hline$\%$ Some College $e_{t-1}$ & $\begin{array}{l}31.59 \\
(3.83)\end{array}$ & \\
\hline$\%$ Univ. Degree $t_{t-1}$ & $\begin{array}{l}10.89 \\
(2.32)\end{array}$ & \\
\hline$\% 12 \leq$ Years Educ $\mathrm{t}_{\mathrm{t}-1}<16$ & & $\begin{array}{l}56.6 \\
(5.2)\end{array}$ \\
\hline$\%$ Bachelor's Degree $_{t-1}$ & & $\begin{array}{l}19.7 \\
(4.2)\end{array}$ \\
\hline Share 15-19 Years Old $\mathrm{t}_{\mathrm{t}-1}$ & $\begin{array}{c}0.077 \\
(0.01)\end{array}$ & $\begin{array}{l}0.074 \\
(0.007)\end{array}$ \\
\hline Share 20-24 Years Old $\mathrm{t}_{\mathrm{t}-1}$ & $\begin{array}{c}0.083 \\
(0.01)\end{array}$ & $\begin{array}{c}0.076 \\
(0.008)\end{array}$ \\
\hline Share 55-64 Years Old ${ }_{t-1}$ & $\begin{array}{l}0.084 \\
(0.007)\end{array}$ & $\begin{array}{l}0.086 \\
(0.008)\end{array}$ \\
\hline Share 65 and Over $_{t-1}$ & $\begin{array}{l}0.115 \\
(0.02)\end{array}$ & $\begin{array}{c}0.127 \\
(0.018)\end{array}$ \\
\hline Manufacturing Share $_{t-1}$ & $\begin{array}{l}0.125 \\
(0.04)\end{array}$ & $\begin{array}{l}0.17 \\
(0.06)\end{array}$ \\
\hline Other Primary Share $\mathrm{t}_{t-1}$ & $\begin{array}{l}0.04 \\
(0.02)\end{array}$ & \\
\hline Mining Share $t_{t-1}$ & & $\begin{array}{c}0.011 \\
(0.02)\end{array}$ \\
\hline Farm Share $_{t-1}$ & $\begin{array}{c}0.054 \\
(0.052)\end{array}$ & $\begin{array}{l}0.041 \\
(0.03)\end{array}$ \\
\hline $\mathrm{N}$ & 140 & 672 \\
\hline
\end{tabular}

Table 2 presents the U.S. and Canadian regression results where employment growth is the primary measure of labor market tightness. Table 3 shows the results when the unemployment rate is the primary labor market indicator. Dividing the tables in this manner eases the comparison of the U.S. and Canadian results. For brevity, the discussion only focuses on the key findings. The control variable results are generally as expected, where they are available from the author. Overall, with only one exception, the 11 "control" variables are jointly significant at the $1 \%$ level, with the exception being significant at the $5 \%$ level. Thus, augmenting the model with the $X$ vector appears warranted. 


\section{TABLE 2}

Wage Growth Regression using Employment Growth as the Labor Market Measure ${ }^{a}$

\begin{tabular}{|c|c|c|c|c|c|c|c|c|}
\hline & \multicolumn{5}{|c|}{ United States } & \multicolumn{3}{|c|}{ Canada } \\
\hline & (1) & (2) & (3) & (4) & (5) & (6) & (7) & (8) \\
\hline & OLS & 2SLS & OLS & 2SLS & OLS & OLS & OLS & OLS \\
\hline & 1984-1997 & 7 1984-91 & $1992-97$ & $1984-91$ & $1992-97$ & $1984-97$ & $1984-97$ & $1984-97$ \\
\hline Ln(Real Week Wage) $)_{t-1}$ & $\begin{array}{l}-0.12 \\
(5.18)\end{array}$ & $\begin{array}{l}-0.23 \\
(1.99)\end{array}$ & $\begin{array}{l}-0.27 \\
(4.50)\end{array}$ & $\begin{array}{l}-0.33 \\
(2.69)\end{array}$ & \begin{tabular}{l|}
-0.28 \\
$(4.72)$
\end{tabular} & $\begin{array}{l}-0.27 \\
(3.65)\end{array}$ & $\begin{array}{l}-0.24 \\
(4.28)\end{array}$ & $\begin{array}{l}-0.26 \\
(3.34)\end{array}$ \\
\hline Employment Growth & $\begin{array}{c}0.179 \\
(5.27)\end{array}$ & $\begin{array}{c}0.434 \\
(5.92)\end{array}$ & $\begin{array}{c}0.124 \\
(1.49)\end{array}$ & $\begin{array}{c}0.696 \\
(5.22)\end{array}$ & $\begin{array}{c}0.158 \\
(1.94)\end{array}$ & $\begin{array}{r}0.300 \\
(3.84)\end{array}$ & $\begin{array}{c}0.258 \\
(3.74)\end{array}$ & $\begin{array}{c}0.289 \\
(3.27)\end{array}$ \\
\hline Employment Growth $\mathrm{t}_{\mathrm{t}-1}$ & $\begin{array}{l}3.1 \mathrm{E}-4 \\
(0.01)\end{array}$ & $\begin{array}{l}0.131 \\
(3.97)\end{array}$ & $\begin{array}{l}-0.036 \\
(0.61)\end{array}$ & $\begin{array}{c}0.306 \\
(3.26)\end{array}$ & $\begin{array}{c}0.004 \\
(0.07)\end{array}$ & $\begin{array}{l}-0.138 \\
(1.96)\end{array}$ & $\begin{array}{l}-0.175 \\
(2.64)\end{array}$ & $\begin{array}{l}-0.213 \\
(2.47)\end{array}$ \\
\hline Employment Growth $\mathrm{t}_{\mathrm{t}-2}$ & $\begin{array}{c}0.102 \\
(3.51)\end{array}$ & $\begin{array}{c}0.024 \\
(0.59)\end{array}$ & $\begin{array}{c}0.151 \\
(3.05)\end{array}$ & $\begin{array}{c}0.075 \\
(1.51)\end{array}$ & $\begin{array}{l}0.124 \\
(2.23)\end{array}$ & $\begin{array}{l}-0.088 \\
(1.95)\end{array}$ & $\begin{array}{l}-0.044 \\
(0.92)\end{array}$ & $\begin{array}{l}-0.108 \\
(2.09)\end{array}$ \\
\hline Employ Grth ${ }_{t}$ x1994plus & & & & & & & $\begin{array}{c}0.500 \\
(4.04)\end{array}$ & \\
\hline Employ Grth $_{\mathrm{t}-1} \times 1994$ plus & & & & & & & $\begin{array}{l}0.584 \\
(3.44)\end{array}$ & \\
\hline Employ Grth $_{\mathrm{t}-2}$ x1994plus & & & & & & & $\begin{array}{l}-0.140 \\
(1.37)\end{array}$ & \\
\hline Unemp Rate $_{t}$ & & & & $\begin{array}{l}0.0088 \\
(2.19)\end{array}$ & $\begin{array}{l}0.0023 \\
(2.30)\end{array}$ & & & $\begin{array}{l}-0.0005 \\
(0.27)\end{array}$ \\
\hline Unemp Rate $_{t-1}$ & & & & $\begin{array}{l}0.0038 \\
(3.04)\end{array}$ & $\begin{array}{l}-0.0010 \\
(1.19)\end{array}$ & & & $\begin{array}{l}-0.002 \\
(0.94)\end{array}$ \\
\hline Unemp Rate $_{t-2}$ & & & & $\begin{array}{l}-0.0038 \\
(2.80)\end{array}$ & $\begin{array}{l}-0.0022 \\
(2.59)\end{array}$ & & & $\begin{array}{c}0.002 \\
(0.86)\end{array}$ \\
\hline$R^{2}$ & 0.799 & 0.823 & 0.815 & 0.679 & 0.824 & 0.597 & 0.656 & 0.602 \\
\hline Hausman F-Statistic ${ }^{\mathrm{b}}$ & $\begin{array}{c}1.34 \\
(p=.261)\end{array}$ & $\begin{array}{c}3.60 \\
(p=.029)\end{array}$ & $\begin{array}{l}0.46 \\
(0.630)\end{array}$ & $\begin{array}{c}6.620 \\
(p=.002)\end{array}$ & $\begin{array}{c}1.27 \\
(p=.286)\end{array}$ & $\begin{array}{r}0.105 \\
(p=.900)\end{array}$ & & $\begin{array}{l}0.062 \\
(0.978)\end{array}$ \\
\hline Sum of Employ Coef ${ }^{c}$ & $\begin{array}{c}0.281 \\
(p=.000)\end{array}$ & $\begin{array}{c}0.589 \\
(p=.0000)\end{array}$ & $\begin{array}{c}0.239 \\
(p=.010)\end{array}$ & $\begin{array}{c}1.077 \\
(\mathrm{p}=.0000)\end{array}$ & $\begin{array}{c}0.286 \\
(p=.012)\end{array}$ & $\begin{array}{r}0.074 \\
(p=.523)\end{array}$ & & $\begin{array}{c}-0.032 \\
(p=.813)\end{array}$ \\
\hline Sum of Emp Coef (pre-1994) & & & & & & & $\begin{array}{c}0.039 \\
(p=.700)\end{array}$ & \\
\hline Sum of Emp Coef (1994-97) ${ }^{c}$ & & & & & & & $\begin{array}{c}0.983 \\
(p=.0002)\end{array}$ & \\
\hline Sum of Unemp Rate Coef ${ }^{d}$ & & & & $\begin{array}{r}0.0088 \\
(p=.019)\end{array}$ & $\begin{array}{r}-0.0009 \\
(p=.576)\end{array}$ & & & $\begin{array}{c}-0.001 \\
(p=.393)\end{array}$ \\
\hline F-Test 1994-97 Emp Inter ${ }^{e}$ & & & & & & & $\begin{array}{c}8.90 \\
(p=.0000)\end{array}$ & \\
\hline
\end{tabular}

aIn parentheses for the variables are the absolute value of the heteroskedastic-consistent $t$-statistics. The table suppresses the results for the other control variables shown in Table 1 as well as the year and region fixed effects.

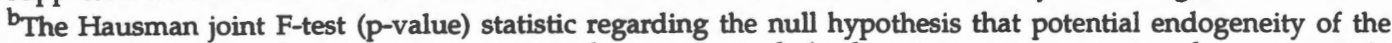
lagged real wage and contemporaneous employment growth (and contemporaneous unemployment rate in columns (4), (5), and (8)) is biasing the coefficients.

${ }^{c}$ The sum of the employment growth coefficients. In parentheses are the p-value from the F-test of the null hypothesis that the sum equals zero.

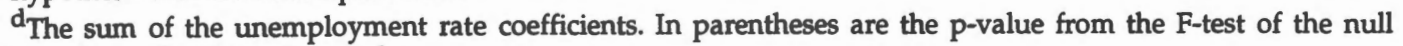
hypothesis that the sum equals zero.

${ }^{\text {e}} \mathrm{F}$-statistic (p-value) of the null hypothesis that the three employment growth $\times 1994$ plus interaction coefficients jointly equal zero. 
TABLE 3

Wage Growth Regression Using the Unemployment Rate as the Labor Market Measure ${ }^{a}$

\begin{tabular}{|c|c|c|c|c|c|}
\hline & \multicolumn{3}{|c|}{ United States } & \multicolumn{2}{|c|}{ Canada } \\
\hline & & (2) & & (4) & (5) \\
\hline & & 2SLS & OLS & OLS & OLS \\
\hline & 1984-1997 & $1984-91$ & $1992-97$ & $1984-97$ & $1984-97$ \\
\hline Ln(Real Week Wage $)_{t-1}$ & $\begin{array}{l}-0.13 \\
(5.52)\end{array}$ & $\begin{array}{l}-0.24 \\
(2.19)\end{array}$ & $\begin{array}{l}-0.27 \\
(4.58)\end{array}$ & $\begin{array}{l}-0.34 \\
(4.48)\end{array}$ & $\begin{array}{l}-0.34 \\
(4.94)\end{array}$ \\
\hline Unemployment Rate $_{\mathrm{t}}$ & $\begin{array}{l}-0.0021 \\
(3.69)\end{array}$ & $\begin{array}{l}-0.0098 \\
(4.88)\end{array}$ & $\begin{array}{l}0.0017 \\
(1.80)\end{array}$ & $\begin{array}{l}-0.0031 \\
(1.61)\end{array}$ & $\begin{array}{l}-0.0034 \\
(1.64)\end{array}$ \\
\hline Unemployment Rate $_{t-1}$ & -0.0005 & -0.0017 & -0.0015 & 0.0035 & 0.0046 \\
\hline & $(0.90)$ & $(2.41)$ & $(1.91)$ & $(1.51)$ & $(1.66)$ \\
\hline${\text { Unemployment } \text { Rate }_{t-2}}$ & -0.0008 & 0.0029 & -0.0021 & 0.0003 & 0.0002 \\
\hline & (1.58) & $(2.90)$ & (2.59) & $(0.19)$ & $(0.11)$ \\
\hline Unemp Rate $_{\mathrm{t}}$ x1994plus & & & & & $\begin{array}{l}-0.0041 \\
(0.93)\end{array}$ \\
\hline Unemp Rate $_{\mathrm{t}-1} \times 1994$ plus & & & & & $\begin{array}{l}-0.0026 \\
(0.63)\end{array}$ \\
\hline Unemp Rate $_{t-2} \times 1994$ plus & & & & & 0.0042 \\
\hline $\mathbf{R}^{2}$ & 0.795 & 0.750 & 0.818 & 0.545 & $\begin{array}{c}(0.98) \\
0.584\end{array}$ \\
\hline & & & & & \\
\hline Hausman F-Statistic ${ }^{b}$ & $\begin{array}{c}0.597 \\
(p=.551)\end{array}$ & $\begin{array}{c}3.30 \\
(p=.038)\end{array}$ & $\begin{array}{c}0.527 \\
(0.591)\end{array}$ & $\begin{array}{c}1.18 \\
(p=313)\end{array}$ & \\
\hline Sum of Unemp Coef ${ }^{c}$ & -0.0034 & -0.0085 & -0.0019 & 0.0007 & \\
\hline Sum of Unemp Coef (pre-1994)c & & & & & $\begin{array}{r}0.0014 \\
(n=378)\end{array}$ \\
\hline Sum of Unemp Coef (1994-97) & & & & & -0.0011 \\
\hline F-Test 1994-97 Unemn Interd & & & & & $(p=.471)$ \\
\hline F-1est 1994-97 Unemp Inter ${ }^{\alpha}$ & & & & & $\begin{array}{c}4.20 \\
(p=.008)\end{array}$ \\
\hline
\end{tabular}

${ }^{a}$ In parentheses for the variables are the absolute value of the heteroskedastic-consistent $t$-statistics. The table suppresses the results for the other control variables shown in Table 1 as well as the year and region fixed effects. ${ }^{b}$ The Hausman joint F-test (p-value) statistic regarding the null hypothesis that potential endogeneity of the lagged real wage and contemporaneous unemployment rate is biasing the coefficients.

${ }^{c}$ The sum of the unemployment rate coefficients. In parentheses are the p-value from the F-test of the null hypothesis that the sum equals zero.

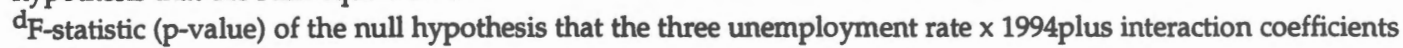
jointly equal zero.

Column 1 of Tables 2 and 3 reports the U.S. results for the base models using employment growth and the unemployment rate, respectively. The bottom of Table 2 shows that a 1 percentage point $(0.01)$ greater U.S. state job growth rate for three years increases real wage growth by approximately 0.28 percent, while Table 3 suggests that a corresponding 1 percentage point greater unemployment rate reduces real wage growth by about 0.34 percent (which is similar to other studies, Stiglitz 1997). ${ }^{19}$ The result is significant at the $1 \%$ level in both cases. Regarding the lagged real wage level, or the error-correction effect, the estimated coefficient is around -0.12 , which closely corresponds to previous research. The relatively small error-correction term suggests that the Phillips curve roughly describes state labor markets. Also, there is little evidence that U.S. wages are

${ }^{19}$ This discussion treats changes in log points as percent changes, which is approximately correct. 
closely linked to productivity as suggested by $(1-\tau) x_{t}$ in Equation $1(\pi=1-\tau)$. Moreover, the response of wages to labor market tightness also implies that the 19841997 period resembles other periods, suggesting little change in the economy.

As noted above, the contemporaneous employment growth rate and unemployment rate may be endogenous. Also, given that the dependent variable is in first-difference form, the lagged real wage variable on the right-hand side might be endogenous. Therefore, the bottom of the tables report Hausman test statistics of the null hypothesis that potential joint endogeneity of contemporaneous employment growth (or the unemployment rate) and the lagged real wage are not biasing the coefficients. ${ }^{20}$ In the employment and unemployment rate models in Column 1, the null is not rejected at the $5 \%$ level, suggesting that endogeneity is not a serious concern and that the pooled model is reliable.

Pooling over the entire sample period implies that wage dynamics remained unchanged. Yet, the new economy view suggests that the dynamics may have shifted in the 1990s. Thus, a pair of Chow tests was conducted to test if the regression coefficients were stable between the 1984-1991 and 1992-1997 periods. The division was chosen simply because it reflects the first complete year of the 1990s economic expansion. ${ }^{21}$ The Chow test rejected the null hypothesis of no structural shift in the coefficients in both cases (for Column 1 in Tables 2 and 3, $\mathrm{F}=2.35, \mathrm{p}=.0001$; and $\mathrm{F}=1.87, \mathrm{p}=.0001$, respectively).

Columns 2 and 3 in Tables 2 and 3 report the results for the regressions when the sample is separated into 1984-1991 and 1992-1997 subperiods. Before proceeding, note that the Hausman test null hypothesis can be rejected at the $5 \%$ level in both 1984-1991 models, but not for either 1992-1997 model. Thus, the results reported in Column 2 of both tables use two-stage least squares (2SLS), treating the lag real wage and the contemporaneous employment growth rate or unemployment rate as endogenous.

\footnotetext{
${ }^{20}$ The instruments in the first-stage equation are the contemporaneous, first, and second lags of the industry mix employment growth rate and the first and second lags of the log of the real weekly wage mix of the state. The industry mix employment growth rate measures the hypothetical employment growth rate that would ensue if all of the region's industries grew at their respective national growth rates. Industry mix job growth simply gauges whether a region has a favorable composition of industries. This measure is often assumed to be the exogenous growth rate that the region could expect due to national patterns and has often been used as an instrument (e.g., BK 1992). Similarly, the real wage mix is the expected earnings in the state if all of its one-digit industries paid their respective national average weekly wages (deflated by the CPI). It is simply a measure of whether the state/province has a composition of high- or low-paying industries (Partridge and Rickman 1995).

${ }^{21}$ Other studies have also found structural breaks. For example, Katz and Krueger (1999) estimate several national and a few state-level Phillips curve models. They detect inward shifts in the Phillips curve in the 1990s as well as a flatter state-level Phillips curve (p. 52). However, their empirical specifications greatly differed. At the state level, they did not include lag measures of the unemployment rate or consider employment growth, their wage measure was quite different, and they did not allow for an error-correction effect. Aaronson and Sullivan (2000), using a traditional Phillips curve approach with state data, detect a slight weakening of the unemployment rateinflation relation in the late 1990s. Alternatively, Staiger, Stock, and Watson (2001) found no change in the slope of the state-level Phillips curves in the 1990s, but their specification so greatly differs from this study that the results are difficult to compare. For example, they did not split the sample periods and their wage measure subtracted off productivity growth. Using national data and different techniques, Stock (1998) found a structural break beginning in 1993, while Atkeson and Ohanian (2001) detect an even earlier break. Yet, the current study focuses on the supposed structural changes that occurred during this economic expansion. The 1990s economic expansion is different for a host of indicators, including a relatively sluggish start to the recovery and the surprising pattern well into the recovery of falling inflation rates even as the unemployment rate fell below 5 percent (Zarnowitz 1999). Conversely, the inflation rate increased as the unemployment rate dipped below the supposed NAIRU level of 6.0 percent during the late 1980s, which is consistent with textbook Phillips curve models.
} 
The results in Columns 2 and 3 in both tables suggest that there are differences between the models. First, the error-correction term in both subperiods is around twice as large as in the pooled models in Column 1. Between 1984 and 1991 , the coefficient on lagged real wages is about -0.23 (significant at the $5 \%$ level). This value is larger than found in prior U.S. studies and is similar to the values found for Europe (BK 1999). Likewise, Column 3 shows that this term is even slightly larger in the latter period $(-0.27)$, which is estimated quite precisely $(t>4.5)$. In both periods, the magnitude of these coefficients suggests that a Phillips curve is not an accurate portrayal of state labor markets. This supports Blanchflower and Oswald's (1994) claim that Phillips curve models are inappropriate. In fact, Whelan (1999) finds that even a "small" error-correction effect like that found here implies stronger supply-side effects (also see BK 1999). Another possibility is that the use of longer sample periods, such as in most Phillips curve studies, may mask the error-correction effect that exists in more homogenous subperiods.

There also appears to be structural changes in the effects of labor market tightness. The bottom of Table 2 shows that a three-year 1 percentage point increase in the job growth rate increases real wage growth by 0.59 percentage point prior to 1992, but by only 0.24 percentage point thereafter (both are significant at the $1 \%$ level). The corresponding change after a 1 percentage point increase in the unemployment rate is -0.85 percentage point before 1992 and -0.19 percentage point thereafter (the 1990 s sum is not even significant at the $10 \%$ level). ${ }^{22}$

The decline in wage responsiveness to labor market tightness somewhat explains why wage growth did not accelerate with the robust labor market performance of the $1990 \mathrm{~s} .{ }^{23}$ Declining wage sensitivity to labor market tightness is consistent with a stronger hysteresis role, but the implied decline in labor market flexibility is implausible. However, new economy explanations for declining wage responsiveness are more plausible. Moreover, these findings support new economy advocates who argue that Federal Reserve policy makers should place more weight on direct inflation indicators and less weight on labor market indicators in forming anti-inflation policies (McTeer 1999).

Even as there are gains to reduced cyclical wage responsiveness, there are also some potential costs. A less cyclically responsive regional labor market slows the adjustment of wages to shocks (a smaller $\beta$ ), which slows factors, such as migration and changes in labor force participation, that bring the economy into equilibrium. The reduced wage response may also increase the persistence of

${ }^{22}$ Further sensitivity analysis was conducted using the production worker hourly wage as the dependent variable. These results also suggested an error-correction term between -0.25 and -0.35 in both periods and that wages were much less cyclically sensitive in the latter 1990s.

${ }^{23} \mathrm{~A}$ similar pattern was produced when the 1984-1991 model was estimated using OLS. For example, the sum of the three employment growth coefficients equaled $0.382(p=.0001)$, while the lagged wage level coefficient equaled 0.25 (although bear in mind that endogeneity is likely affecting the results). Regardless, the difference between the wage response to employment growth in the 1980s and 1990s is still statistically significant at the $10 \%$ level (one tail), even as the significance is reduced due to the imprecision of the 1992-1997 estimate (a similar pattern follows for the unemployment rate). Likewise, a similar pattern is produced after dropping the lagged wage level and estimating the model by OLS (to correspond even more closely to the typical Phillips curve). The sum of the job growth coefficients in the 1984-1991 and 1992-1997 models equaled 0.402 and 0.213, respectively, which are significantly different at the $5 \%$ level (one tail). 
regional unemployment rates (Jimeno and Bentolila 1998). Although regional recessions during the latter 1990s were not a problem, there were a series of "rolling" recessions in the 1980s and early 1990s (e.g., in the farm belt, rust belt, oil patch, California, New England). A decline in regional wage responsiveness suggests that economies may have a harder time adjusting to future regional downturns.

Dividing the sample into the 1984-1991 and 1992-1997 time periods has the simple advantage of examining changes during the 1990s economic expansion (while a practical advantage is that this dividing point yields relatively large sample sizes in both periods). Yet, alternative regressions (not shown) were estimated using nearby periods to check the sensitivity of the findings. For instance, breaking the sample into 1984-1990 and 1991-1997 periods yields almost equal sum of squared residuals over the entire sample period. The error-correction term was insignificantly different from zero in the early period $(t \approx 1.5)$, but was about -0.21 $(t \approx 4.0)$ in the latter period for both the employment growth and unemployment models. Likewise, wages were also less sensitive to labor market strength in the 1991-1997 period. Separating the sample into 1984-1992 and 1993-1997 time periods generated a larger sum of the squared residuals than the models shown in the tables, although the results are consistent with the reported findings. Overall, simply focusing on the ongoing economic expansion appears reasonable.

To examine further the robustness of these results, additional sensitivity analysis was conducted by omitting the $11 \mathrm{X}$ vector control variables from the models shown in Columns 2 and 3 of Tables 2 and 3 (not shown). This more closely reflects the parsimonious specifications generally used in the literature. In this case, the labor market tightness variables continue to suggest a smaller wage responsiveness to state cyclical conditions in the 1990s. For example, the sum of the job growth coefficients equaled 0.39 for the 1984-1991 period and 0.26 for the 1992-1997 period, while the corresponding figures for the unemployment rate response were -0.58 percent and -0.25 percent. Second, the error-correction effect is much smaller in the earlier period. For example, using the employment growth rate as the labor market tightness measure, the lag real wage coefficient equaled $0.02(t=0.41)$ and $-0.19(t=3.81)$ for the 1984-1991 and 1992-1997 periods, respectively. In other results (not shown), the lagged real wage was dropped to correspond to a pure Phillips curve model, but the wage responses were similar to those described above. Overall, the reported results do not appear to be artifacts of functional form.

The above sensitivity results and the base model findings in Columns 2 and 3 of both tables provide some hint of a slightly greater error-correction term after 1991. This would mean that wages are more closely linked to firm and individual productivity (BK 1999). However, because productivity could show up in many ways in this model, this conclusion is only tentative.

The models in Columns 4 and 5 of Table 2 include both the unemployment rate and the employment growth rate as measures of labor market tightness to examine wage dynamics further. Following from the joint Hausman test results, 
the 1984-1991 model was estimated using 2SLS. The 1984-1991 results suggest that when the unemployment rate is included, wage responsiveness to employment growth almost doubles (0.589 versus 1.077$)$. Yet, the unemployment rate is now positively related to wages, which is significant at the $5 \%$ level (consistent with Partridge and Rickman 1997a). For the latter 1990s, with the unemployment rate being controlled for, the responsiveness of wages to employment growth is also slightly higher in Column 5 (significant at the $5 \%$ level). Yet, with job growth in the model, the responsiveness of wages in Column 5 to the unemployment rate is less than one-half of the case of when employment was not included (in Column 3 of Table 3). Moreover, the sum of the unemployment coefficients is not significant at the $5 \%$ level.

One question is why did the unemployment rate response, controlling for employment growth, move from being positive in the 1980s (consistent with a HarrisTodaro model) to being negative (as in the theoretical models in Section 2)? One answer might be the greater duration of unemployment spells during the 1990s. The long-term unemployment rate (greater than six months) sharply increased in the 1990s, controlling for business cycle strength (Katz and Krueger 1999; Partridge and Rickman 1998). Likewise, Dalenberg and Partridge (2000) find the influence of the long-term unemployment rate abruptly changed from being positively related to wages (as in insider-outsider models) to being negatively related to wages in the 1990s (perhaps from worker anxiety). Thus, the combination of greater long-term unemployment rates and higher worker anxieties may explain why the unemployment rate effect became more negatively related to wage growth during the 1990s (e.g., Greenspan 1997). However, the results in Column 4 should be interpreted cautiously. For example, the error-correction effect is higher than any other 1984-1991 model and the wage responsiveness to employment growth is quite high.

The results in Columns 4 and 5 of Table 2 also suggest that employment growth is a superior measure of labor market tightness at the state level. The sum of the employment coefficients is consistently the same sign as expected, while this is not always true for the unemployment rate. The job growth results are also more robust and the statistical significance tends to be superior.

Now turn to the Canadian results in Columns 6, 7, and 8 of Table 2 and Columns 4 and 5 of Table 3. First, Column 6 of Table 2 and Column 4 of Table 3 contain the base provincial models that use only the job growth rate and the unemployment rate, respectively, as the measure of labor market strength. Before proceeding, note that the joint Hausman tests regarding the potential endogeneity of the lag real wage and the contemporaneous measures of labor market tightness are always insignificant.

The Canadian coefficient on the lag real wage is significant. In both the job growth and unemployment rate cases, the error-correction term is at least as high as for the U.S. This suggests that a Phillips curve is not an appropriate model of Canadian regional labor markets. 
The sum of both the employment growth and the unemployment coefficients are close to zero and insignificant. ${ }^{24}$ The finding that labor market tightness has no long-run influence on Canadian wages is consistent with hysteresis and wage rigidity, but the finding is also consistent with the new economy hypothesis. Yet, it seems unlikely that the new economy hypothesis strongly applied to Canada for the entire 1984-1997 period. Over the period, the small average wage response to regional labor market tightness dampened the migration and labor force participation responses that restore equilibrium. ${ }^{25,26}$

Even as unemployment rates remained stuck at high levels during most of the 1990s, the Canadian economy was exposed to many of the same forces as the U.S. To explore this issue further, the employment growth rate or the unemployment rate is interacted with an indicator that reflects the post-1993 period (1994 and later). The post-1993 period was selected because the Canadian labor market did not really tighten after the early 1990s recession until 1994, when the unemployment rate and the employment/population ratio began to show clear improvement. ${ }^{27}$

Regarding the employment growth results, the bottom of Column 7 in Table 2 shows that the sum of the job growth coefficients is insignificant before 1994 , but there is a statistically significant positive shift in the latter period. In fact, for 1994 and after, provincial wage growth responds more to job growth than did state wages between 1984-1991. This suggests that Canadian wage rigidity weakened. However, unlike the U.S., this change is not consistent with strong new economy effects. On the plus side, this implies that Canada will better be able to adjust to regional economic shocks (and may have a declining NAIRU). Yet, this also suggests that if Canada experienced extremely tight labor markets as in the U.S., Canada would more likely experience wage inflation. ${ }^{28}$ In other sensitivity

${ }^{24}$ Although the sum of the employment growth coefficients is statistically insignificant, a joint F-test on all three employment growth rate variables was significant $(F=6.57, p=.0004)$. Thus, even as their net impact is near zero, job growth rates individually are significant determinants of wage dynamics. Conversely, a joint F-test on the three unemployment rates was insignificant ( $F=1.77, p=.157)$. This supports the notion that job growth is a superior regional labor market measure.

25 In sensitivity analysis, substituting the manufacturing hourly wage for the total civilian weekly wage produced an even larger error-correction term (about -0.45 , not shown). Like the weekly earnings results, the sum of the employment growth coefficients was insignificant, but the sum of the unemployment rate coefficients was positive and significant at the $10 \%$ level, which is the Harris-Todaro result (i.e., not pro-cyclically responsive). Unlike the U.S., Canada produces provincial measures of hourly wages for total civilian employment. Using this measure (not shown), the coefficient on the error-correction term was also about -0.45 . The sum of the unemployment rate coefficients was insignificant, although the sum of the job growth coefficients equaled 0.35 , which was significant at the $10 \%$ level.

26In another sensitivity run, the provincial wage deflator was replaced by the national deflator to create a wage measure that corresponds to the U.S. measure. However, the findings were quite similar except that the unemployment rate effect was slightly larger.

${ }^{27}$ Sensitivity analysis examining shifts for earlier years suggested that this division produced a better fit (not shown). For example, using the employment growth rate as the labor market measure, the $\mathrm{R}^{2}$ statistics using a post-1992 indicator equaled 0.61, while the $R^{2}$ equaled 0.60 when a post-1991 indicator was used (versus 0.66 for the case reported in the tables). It would be preferable to have split the data set into two samples like the U.S. case. However, the resulting post-1993 sample size would have only been 40, which is far too small when controlling for year and provincial fixed effects.

${ }^{28}$ Akerlof, Dickens, and Perry (2000) contend that the U.S. Phillips curve was flatter in the latter 1990s because the inflation rate was low. They reasoned that firms and workers engage in "near-rational" wage and price setting, where workers essentially ignore inflation when it is low because the costs of doing so are relatively small. The apparent steepening of the Canadian Phillips curve during this period is evidence against their hypothesis because Canada also experienced low inflation. 
analysis (not shown), the lagged real wage was also interacted with the post-1993 indicator dummy to examine whether there was a corresponding shift in the errorcorrection term. Yet, the coefficient on this interaction was less than 0.03 with a t-statistic under 1.0, suggesting no change in the error-correction effect.

Somewhat weaker findings follow from the unemployment rate results in Column 5 of Table 3. Consistent with the effects of labor market tightness becoming more important, the sum of the post-1993 unemployment rate coefficients becomes negative. Yet, the sums of the unemployment rate coefficients both before and after 1993 are still insignificant. However, the last row shows that the three post-1993 unemployment rate coefficients are jointly statistically significant, suggesting that there was a small negative shift in the provincial wage response to unemployment rates.

The model in Column 8 of Table 2 includes both employment growth and the unemployment rate. The sum of the job growth and the unemployment rate coefficients remain insignificant. A joint F-test on the employment growth coefficients suggests that they are jointly significant at the $0.001 \%$ level $(F=6.13)$ (not shown), but a joint F-test on the unemployment rates is nowhere near statistically significant $(\mathrm{F}=0.61)$ (not shown). This again implies that over the entire sample period, job growth affects the short-term dynamics of wage formation, but its long-term net effect is near zero. Like the U.S. results, these results suggest that job growth is a superior measure of provincial labor market tightness.

\section{CONCLUSION}

The outstanding performance of U.S. labor markets during the 1990s indicates that structural changes may have occurred. This study examined the issue by estimating regional Phillips curve models augmented by an error-correction effect to make the model more consistent with theoretically oriented models. To highlight further any changes, a comparison was made to Canadian wage dynamics, since, like most other advanced countries, Canada did not experience as favorable of a labor market climate.

The U.S. (and Canadian) results indicate that employment growth is superior to unemployment rates as a measure of regional labor market tightness. The U.S. results also suggest that there was a smaller cyclical response of wages to state labor market tightness during the 1990s, ceteris paribus. On the positive side, this suggests that inflationary pressures will be less likely to build in tight state labor market conditions, implying that there is a lower cost for Federal Reserve policy makers to allow very low unemployment rates to persist. On the negative side, this suggests that U.S. labor markets are less flexible in terms of regional shocks, which may slow adjustments to future regional downturns. Similarly, the reduced trade-off implies that the time inconsistency problem may be more likely to arise in the future because the Federal Reserve would be able to gain temporary reductions in unemployment at a relatively small cost. Yet, as workers begin to incorporate this behavior into their expectations, inflation would begin to accelerate. 
In fact, Sargent (1999) fears that as the experience of the Great Inflation of the 1970s fades from the public's memory, this possibility will greatly increase.

The U.S. findings reveal little error-correction effect when considering the entire sample period, but a larger error-correction effect when dividing the sample into subperiods that correspond to the 1990s economic expansion. The largerthan-expected error-correction effect suggests that Phillips curve models do not apply in either period. The results also weakly indicate a greater error-correction effect in the latter 1990s. If so, this very tentatively means that there was a greater wage aspiration effect, as well as a closer link between individual and firm performance and wages.

The Canadian results also indicate a relatively large error-correction effect, suggesting that a Phillips curve model is inappropriate. The Canadian findings suggested that hysteresis has played a role, indicating a sluggish adjustment process in provincial labor markets. However, in the latter 1990s, Canadian wages appear to have become more responsive to labor market tightness, which is the opposite of the U.S. case. This disparity suggests that U.S. regional labor market changes may be atypical.

Future research should focus on why contrasting changes took place in the U.S. and Canada, even as both are exposed to similar economic trends. For example, why did new economy forces seemingly affect the U.S. before Canada, and do recent labor market improvements since 1998 suggest that the new economy is now affecting Canada to a stronger degree?

\section{REFERENCES}

Aaronson, D., and D. Sullivan. "Unemployment and Wage Growth: Recent CrossState Evidence." Economic Perspectives 24 (2000), 54-71.

Akerlof, G.A., W.T. Dickens, and G.L. Perry. "Near-Rational Wage and Price Setting and the Long-Run Phillips Curve." Brookings Papers on Economic Activity (2000), 1-60.

Atkeson. A., and L.E. Ohanian. "Are Phillips Curves Useful for Forecasting Inflation?" Federal Reserve Bank of Minneapolis Quarterly Review 25 (2001), 2-11.

Blanchard, O., and L.F. Katz. "Regional Evolutions." Brookings Papers on Economic Activity (1992), 1-75.

. "What We Know and Do Not Know About the Natural Rate of Unem-

ployment." Journal of Economic Perspectives 11 (1997), 51-72.

. "Wage Dynamics: Reconciling Theory and Evidence." American Economic Review 89 (1999), 69-74.

Blanchard, O., and L.H. Summers. "Hysteresis in the European Unemployment Problem." In S. Fischer (ed.) NBER Macroeconomics Annual 1986. Cambridge, MA: MIT Press, 1986.

Blanchflower, D., and A. Oswald. The Wage Curve. Cambridge, MA: MIT Press, 1994. Brayton, F., J.M. Roberts, and J.C. Williams. "What Happened to the Phillips Curve?" Federal Reserve Board of Governors Finance and Economics Discussion Series, \#1999-49. Washington, D.C., September 1999. 
Card, D., F. Kramarz, and T. Lemieux. "Changes in the Relative Structure of Wages and Employment: A Comparison of the United States, Canada, and France." NBER Working Paper \#5487. Cambridge, MA: National Bureau of Economic Research, March 1996.

Card, D., and W.C. Riddell. "A Comparative Analysis of Unemployment in Canada and the United States." In D. Card and R. Freeman (eds.) Small Differences That Matter. Chicago: NBER, 1993.

Dalenberg, D., and M.D. Partridge. "An Empirical Analysis of State Labor Markets: Has Worker Insecurity Shifted Wages in the 1990s?" Quarterly Review of Economics and Finance 40 (2000), 303-323.

Decressin, J., and A. Fatás. "Regional Labor Market Dynamics in Europe." European Economic Review 39 (1995), 1627-1655.

De Long, J.B. "America's Peacetime Inflation: The 1970s." In C. Romer and D. Romer (eds.) Reducing Inflation: Motivation and Strategy. Chicago: University of Chicago Press, 1997.

Fortin, P. "The Unbearable Lightness of Zero-Inflation Optimism." In B. MacLean and L. Osberg (eds.) The Unemployment Crisis: All for Nought? Montreal: McGill-Queen's University Press, 1996.

Franz, W., and R. J. Gordon. "German and American Wage and Price Dynamic, Differences and Common Theme." European Economic Review 37 (1993), 719-754.

Freeman, R.B. "War of the Models: Which Labour Market Institutions for the 21st Century?" Labour Economics 5 (1998), 1-24.

. "The US Economic Model at Y2K: Lodestar for Advanced Capitalism?"

NBER Working Paper \#7757. Cambridge, MA: National Bureau of Economic Research, June 2000.

Freeman, R.B., and W.M. Rodgers. "Area Economic Conditions and the Labor Market Outcomes of Young Men in the 1990s Expansion." NBER Working Paper \#7073. Cambridge, MA: National Bureau of Economic Research, April 1999.

Gordon, R J. "The Time-Varying NAIRU and its Implications for Economic Policy." Journal of Economic Perspectives 11 (1997), 11-32.

. "Foundations of the Goldilocks Economy: Supply Shocks and the Time-

Varying NAIRU." Brookings Papers on Economic Activity (1998), 297-346.

Greenspan, A. "Humphrey-Hawkins Monetary Policy Testimony." February 26, 1997. <http://www.bog.frb.fed.us/boarddocs/hh/9702test.htm>.

Harris, J.R., and M.P. Todaro. "Migration, Unemployment and Development: A Two-Sector Analysis." American Economic Review 60 (1970), 126-142.

Hirsch, B.T., and D.A. Macpherson. "Union Membership and Coverage Files from the Current Population Surveys: Note." Industrial and Labor Relations Review 46 (1993), 574-578.

Hyclak, T., and G. Johnes. Wage Flexibility and Unemployment Dynamics in Regional Labor Markets. Kalamazoo, MI: Upjohn Institute, 1992. 
Ireland, P.N. "Does the Time Consistency Problem Explain the Behavior of Inflation in the United States." Journal of Monetary Economics 44 (1999), 279-291.

Jaeger, A., and M. Parkinson. "Some Evidence on Hysteresis in Unemployment Rates." European Economic Review 38 (1994), 329-342.

Jimeno, J.F., and S. Bentolila. "Regional Unemployment Persistence: Spain 19761994." Labour Economics 5 (1998), 25-52.

Johnson, J.A., and R.D. Kneebone. "Wage Flexibility and Cyclical Unemployment in Canadian Provinces." Canadian Journal of Regional Science 16 (1993), 1-19.

Jorgenson, D.W., and K.J. Stiroh. "Raising the Speed Limit: U.S. Economic Growth in the Information Age." Brookings Papers on Economic Activity (2000), 125-235.

Katz, L.F., and A.B. Krueger. "The High-Pressure U.S. Labor Market." Brookings Papers on Economic Activity (1999), 1-87.

Kuhn, P., and L.A. Robb. "Shifting Skill Demand and the Canada-US Unemployment Gap: Evidence from Prime-Age Men." Canadian Public Policy 24 (1998), 170-191.

Kydland, F.E., and E.C. Prescott. "Rules Rather Than Discretion: The Inconsistency of Optimal Plans." Journal of Political Economy 85 (1977), 473-491.

Lindbeck, A., and D. Snower. The Insider-Outsider Theory of Employment and Unemployment. Cambridge, MA: MIT Press, 1988.

Mandel, M.J. "How Most Economists Missed the Boat." Business Week, 29 October 1999, 100-106.

Mayer, T. Monetary Policy and the Great Inflation in the United States. Northampton, MA: Edward Elgar, 1999.

McTeer, B. "Believe Your Eyes. The New Economy is Real." Wall Street Journal, 18 November 1999, A26.

Nickell, S. "Unemployment: Questions and Some Answers." Economic Journal 109 (1998), 802-816.

Nordhaus, W. "General Discussion of The High-Pressure U.S. Labor Market." Brookings Papers on Economic Activity (1999), 79-81.

Parkin, M. "Inflation in North America." In K. Shigehara (ed.) Price Stability in the 1990s. London: Macmillan, 1993.

Partridge, M.D., and D.S. Rickman. "Differences in State Unemployment Rates: The Role of Labor and Product Market Structural Shifts." Southern Economic Journal 62 (1995), 89-106.

. "Has the Wage Curve Nullified the Harris-Todaro Model? Further U.S. Evidence." Economic Letters 54 (1997a), 277-283.

."The Dispersion of US State Unemployment Rates: The Role of Market and Non-Market Equilibrium Factors." Regional Studies 31 (1997b), 593-606. "Regional Differences in Chronic Long-term Unemployment." Quarterly Review of Economics and Finance 38 (1998), 193-215.

. "A Note on the Benefits to Current Residents of State Employment Growth: Is There an Industry Mix Effect on Migration." Journal of Regional Science 39 (1999), 167-181. 
Phelps, E. "Lessons in Natural Rate Dynamics." Oxford Economic Papers 52 (2000), 51-71.

Riddell, W.C., and A. Sharpe. "The Canada-US Unemployment Rate Gap: An Introduction and Overview." Canadian Public Policy 24 (1998), 1-37.

Sargent, T.J. The Conquest of American Inflation. Princeton, NJ: Princeton University Press, 1999.

Schlesinger, J.M. "The Outlook, Worker-Capitalists of the World, Unite." Wall Street Journal, 15 November 1999, A1.

Sims, C. A. "Drift and Breaks in Monetary Policy." Working paper, Princeton University, Princeton, NJ, July 1999.

Solon, G., R. Barsky, and J.A. Parker. "Measuring the Cyclicality of Real Wages: How Important is the Composition Bias?" Quarterly Journal of Economics 109 (1994), 1-25.

Song, F.M., and Y. Wu. "Hysteresis in Unemployment: Evidence from OECD Countries." Quarterly Review of Economics and Finance 38 (1998), 181-192.

Staiger, D., J.H. Stock, and M.W. Watson. "The NAIRU, Unemployment and Monetary Policy." Journal of Economic Perspectives 11 (1997), 33-49.

. "Prices, Wages and the U.S. NAIRU in the 1990s." NBER Working Paper \#8320. Cambridge, MA: National Bureau of Economic Research, June 2001.

Statistics Canada. CANSIM CD-ROM Disk, 1998-2.

Stiglitz, J. "Reflections on the Natural Rate Hypothesis." Journal of Economic Perspectives 11 (1997), 3-10.

Stock, J.H. "Comments and Discussion." Brookings Papers on Economic Activity (1998), 334-346.

Taylor, J.B. "Comment." In C. Romer and D. Romer (eds.) Reducing Inflation: Motivation and Strategy. Chicago: University of Chicago Press, 1997.

U.S. Department of Labor. Bureau of Labor Statistics. "Comparative Civilian Labor Force Statistics, Ten Countries, 1959-1998." Washington, D.C., April 1999.

Whelan, K. "Wage Curve vs. Phillips Curve: Are There Macroeconomic Implications." Federal Reserve Board of Governors Finance and Economics Discussion Series, \#1997-51. Washington, D.C., October 1997.

. "Real Wage Dynamics and the Phillips Curve." Federal Reserve Board of Governors Finance and Economics Discussion Series, \#2000-2. Washington, D.C., December 1999.

Zarnowitz, V. "Theory and History Behind Business Cycles: Are the 1990s the Onset of a Golden Age?" Journal of Economic Perspectives 13 (1999), 69-90. 
